Communication

\title{
Dispersed Geoheritage Points of the Lagonaki Highland, SW Russia: Contribution to Local Geoheritage Resource
}

\author{
Dmitry A. Ruban ${ }^{1,2}, \mathbb{C}^{\mathbb{D}}$, Svetlana O. Zorina ${ }^{3}$ and Maksim B. Rebezov ${ }^{1,4,5,6}$ \\ 1 K.G. Razumovsky Moscow State University of Technologies and Management (the First Cossack University), \\ Zemlyanoy Val 73, Moscow 109004, Russia \\ 2 Department of Economics and Management, Business School, Cherepovets State University, \\ Sovetskiy Avenue 10, Cherepovets, Vologda Region 162600, Russia \\ 3 Kazan (Volga Region) Federal University, Kremlyovskaya Street 18, \\ Kazan, Republic of Tatarstan 420008, Russia \\ 4 South Ural State University, Lenin Avenue 76, Chelyabinsk 454080, Russia \\ 5 Ural State Agrarian University, Karl Liebknecht Street 42, Yekaterinburg 620075, Russia \\ 6 V.M. Gorbatov Federal Research Center for Food Systems of Russian Academy of Sciences, Talalikhin Street 26, \\ Moscow 109316, Russia \\ * Correspondence: ruban-d@mail.ru
}

Received: 7 August 2019; Accepted: 22 August 2019; Published: 23 August 2019

\begin{abstract}
Dispersed geoheritage points, which are small-sized and low-unique localities, manifest local geoheritage and, thus, may be useful for its comprehensive understanding. Field studies in the Lagonaki Highland (Western Caucasus, southwestern Russia) have permitted to find four geoheritage points that are described with argumentation of their importance to scientists, educators, and/or tourists. These points, none of which can be defined as a 'traditional' geosite, provide some precious sedimentary, palaeontological, and mineralogical information that improves perception of the local geoheritage landscape dominated by the Late Jurassic carbonate platform deposits. The studied localities are constituents of the local geoheritage resource because of their utility to three main categories of potential users. Scientists may be interested in these dispersed geoheritage points because of the need to collect massive geological data from big areas. Educators and tourists may appreciate these points because of their location along principal roads, i.e., their good accessibility.
\end{abstract}

Keywords: calcite vein; fossil invertebrate; geoconservation; geosite; landscape management; limestone; tourism; late jurassic; western caucasus

\section{Introduction}

Geological heritage (geoheritage) is an important resource for geoscience research, education, and (geo)tourism [1-7]. Geoheritage sites (geosites) are the main constituents of this resource, and these are employed taken alone, in groups, or in the form of geopark creation. Principles of their selection and description are well-fixed in the literature [8-10]. However, geoheritage is a vast category, and the full spectrum of its manifestations is yet to be registered. For instance, Migoń and Pijet-Migoń [11] have distinguished viewpoint geosites offering panoramic views of large-scale geological features as a new kind of geosites. When geoheritage resource of any territory is evaluated, it seems to be insufficient to restrict it to only 'traditional' geosites, i.e., geological sites of evident uniqueness. Other manifestations of geological phenomena can add value (even significant value) to this resource.

Geoheritage landscapes are landscapes occupying areas of certain size (big or small) dominated by well-visible, unique geological features [12]. Such landscapes are characterized by multiple, 
potentially-interesting (to scientists, educators, and tourists) phenomena that can be represented either in geosites or other outcrops. Although the latter cannot be judged full-scale, 'traditional' geosites because of their 'trivial' nature (i.e., very low uniqueness), these should not be missed as manifestations of the really unique territorial geoheritage. On the one hand, these permit to feel the very geoheritage dominance in a given landscape. On the other hand, such outcrops can contribute to massive data extraction from this landscape by Earth scientists, or these are located close to roads and trails offering better geological vision to educators and tourists. It is proposed to distinguish such objects as dispersed geoheritage points. The word 'dispersed' is used because it is the spatial distribution of these features that makes them really valuable to geoheritage landscape comprehension. The word 'point' determines less importance relatively to 'traditional' geosites and often (but necessary) small size. Geosites can be of international (global), national, regional (provincial), or local importance depending on their uniqueness. In contrast, the proposed geoheritage points are not unique at all when taken individually. However, they reflect uniqueness of a given geoheritage landscape and make this uniqueness sharper because they enlarge the entity of geoheritage manifestations. In the other words, dispersed geoheritage points look like splitters of costly glass. Splitters have some value (even if minimal) only if the value of unbroken glass is recognized. The need for recognition of dispersed geoheritage points is dictated by availability of geoheritage landscapes occupying big areas.

A typical example of geoheritage landscape is the Lagonaki Highland in the Western Caucasus, on the territory of southwestern Russia (Figure 1A). Its geological setting can be deduced from Adamia et al. [13], Guo et al. [14], Ruban [15], Saintot et al. [16], and Veress et al. [17]. Generally, this elevated ( $2000 \mathrm{~m})$ territory is a domain of the Cenozoic fold-and-thrust belt of the Greater Caucasus, and it is dominated by the Late Jurassic carbonate platform deposits accumulated in a back-arc basin, numerous epikarst and endokarst features, and cuesta-type mountain ranges. The high geoheritage value of the Lagonaki Highland is undisputable and already established [12], as well as its resource potential for science, education, and tourism. However, a kind of challenge of this geoheritage resource exploitation is its big size and manifestation of unique features in numerous, small, and often difficult-to-access localities. These can be judged dispersed geoheritage points. The objective of the present paper is to provide the first characteristics of some of these localities in order to demonstrate their utility as constituents of the local geoheritage resource.
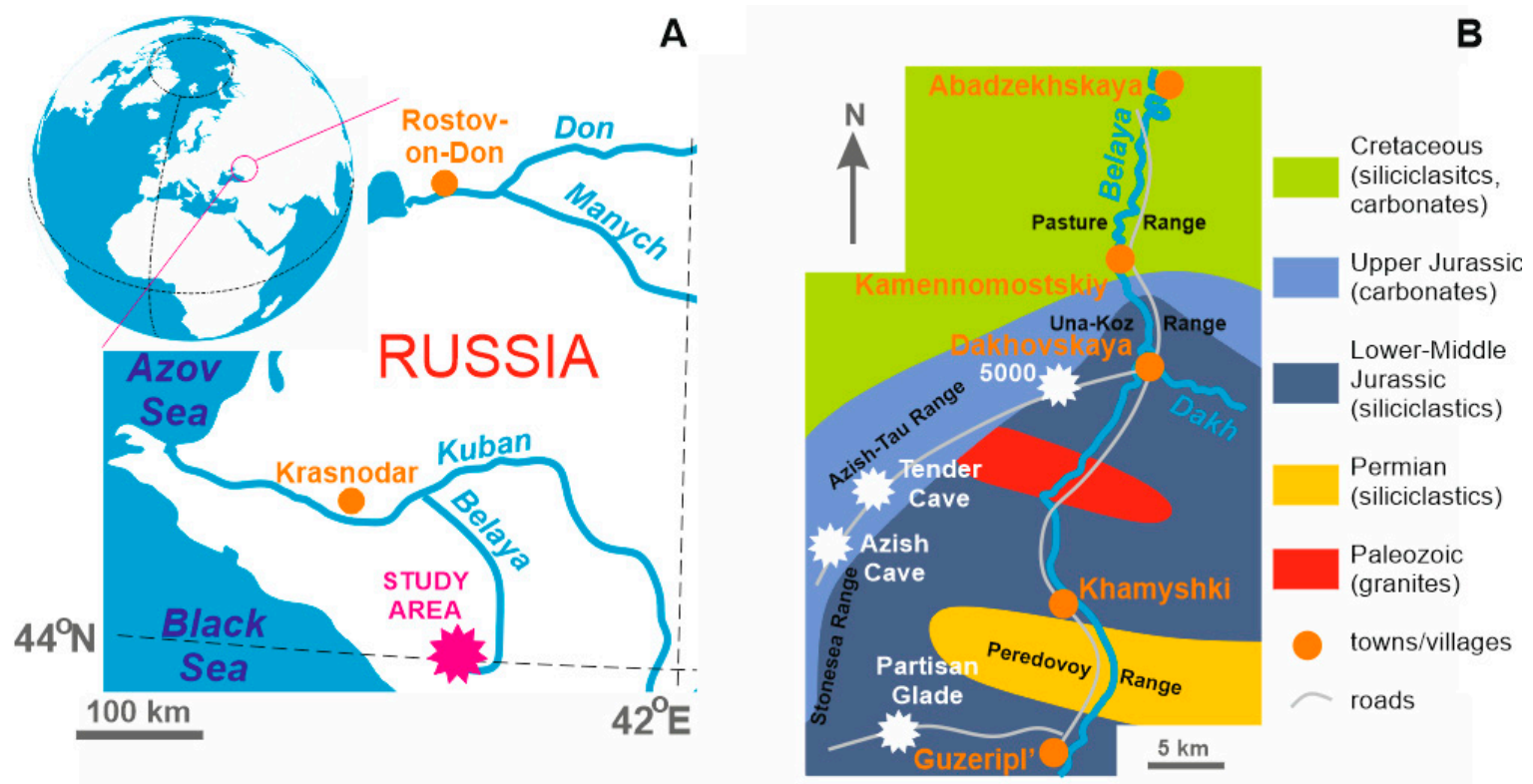

Figure 1. Geographical location of the study area (A) and the dispersed geoheritage points (B). 


\section{Materials and Methods}

The Lagonaki Highland is understood differently. Most often, it is treated as an area restricted to the Stonesea Range and the surrounding cuesta-type mountain ranges. In this case, this is one single geosite of global value [12]. However, the Lagonaki Highland can be interpreted as a bigger geographical domain that includes also wide peripheries of the above-mentioned core and some other ranges (e.g., the Azish-Tau Range). This second option is preferred in this study. In this case, the above-mentioned geosite is the core of the highland, and smaller rock outcrops with very restricted (if any) uniqueness occur on its peripheries.

This study is based on the material collected in the course of field investigations conducted during the summer campaigns in 2015-2019. The eastern and southern parts of the Lagonaki Highland have been surveyed in order to find manifestations of its geoheritage resource. In this case, the entire geological environment of the highland is considered as a geoheritage, and, thus, all rock exposures in natural outcrops and roadcuts are considered as this geoheritage manifestations. In the other words, the very existence of a given manifestation on the geologically valuable area is enough to consider this manifestation. The only selection criterion is representation of the geological phenomenon (a) typical for this area. Particularly, four small localities have been found in the course of field search for rock exposures (first of all, along the main roads where the demand for geoheritage manifestations is especially high). These are outcrops representing peculiarities of rocks, minerals, and fossils of the study area (Figures 1B and 2). These localities manifest the local geoheritage and, thus, permit to feel its uniqueness if even their own uniqueness is restricted. As these are not 'traditional' geosites by definition, it seems to be unreasonable to describe them formally as geosites with the application of the well-known approaches [8-10].
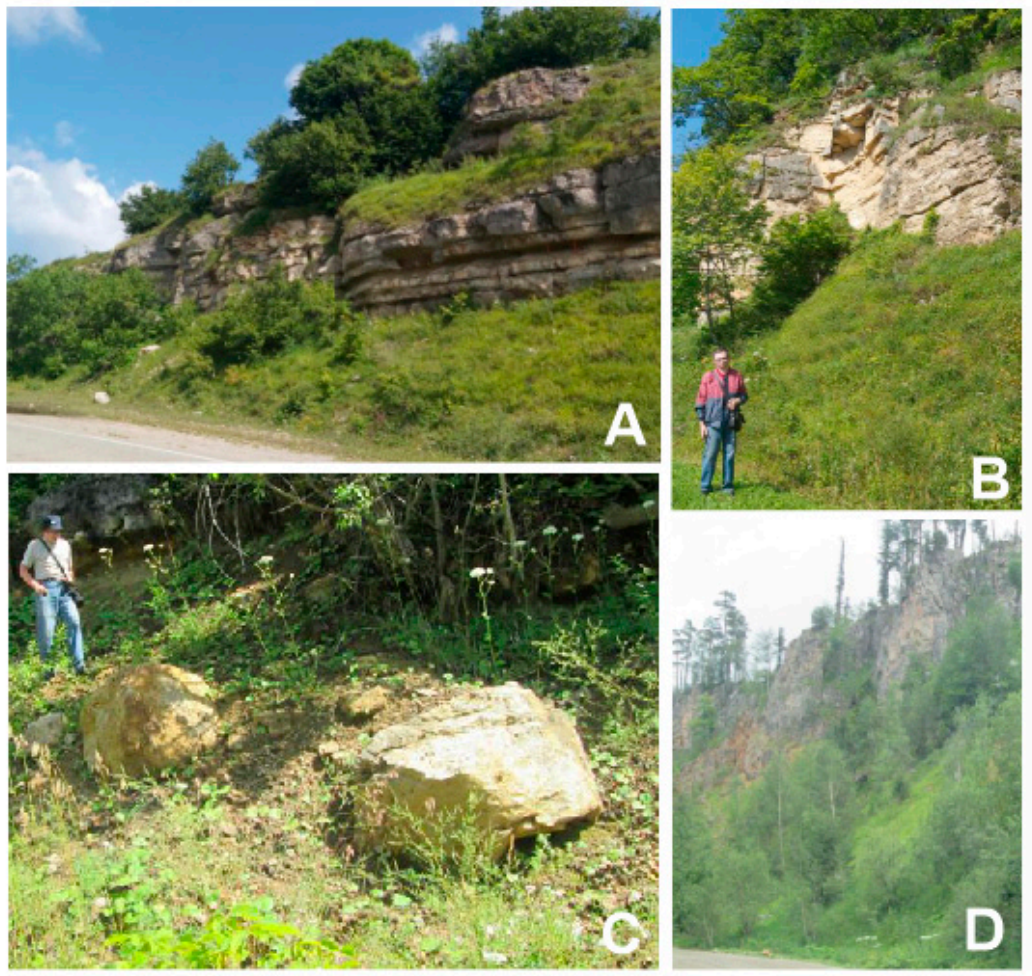

Figure 2. The studied localities: (A) Tender Cave, (B) 5000, (C) Partisan Glade, and (D) Azish Cave.

All four localities were examined in the field, and the key features relevant to the local geoheritage were registered. The utility of these localities to scientists, educators, and tourists was established, and the relevant arguments are presented in this paper. Some special analytical procedures were conducted later. These included analysis of thin sections of carbonate rocks, analysis of their mineral 
composition using X-ray powder diffraction method, major and trace element geochemistry, and analysis of $\delta^{13} \mathrm{C}(\mathrm{PDB})$ value using $\mathrm{X}$-ray fluorescence wave-dispersion spectrometry and inductively coupled plasma mass spectrometry at the laboratories of the Institute of Geology and Petroleum Technologies at Kazan Federal University (Kazan, Russia). These lithological and geochemical studies are necessary to stress some peculiarities of the exposed rocks, i.e., their uniqueness and utility, say to geoscientists.

\section{Results}

The first geoheritage point is the Tender Cave locality where ammonites (Figures 2A and 3A) and some other marine macroinvertebrates have been found in the Late Jurassic limestones. The importance of this geoheritage point to scientists is linked to significant potential of the noted fossils to solution of many still existing problems of regional and local stratigraphy [15]. For instance, stratigraphical relationship of limestone layers represented in the lengthy (up to $40 \mathrm{~km}$ ), but too fragmented section along the Lagonaki-Dakhovskaya road remains very unclear; as the Tender Cave locality is a constituent of this section, palaeontological data from there can be very useful. To educators, this point with highly fossiliferous limestones is valuable to demonstrate existence of rich ecosystems in an ancient tropical sea. As for tourists, fossil amateurs may be really interested in collecting at this locality, which is possible without risks for impoverishment of the local palaeontological record: Fossils are attractive, but very obvious and occurring widely on the study area.

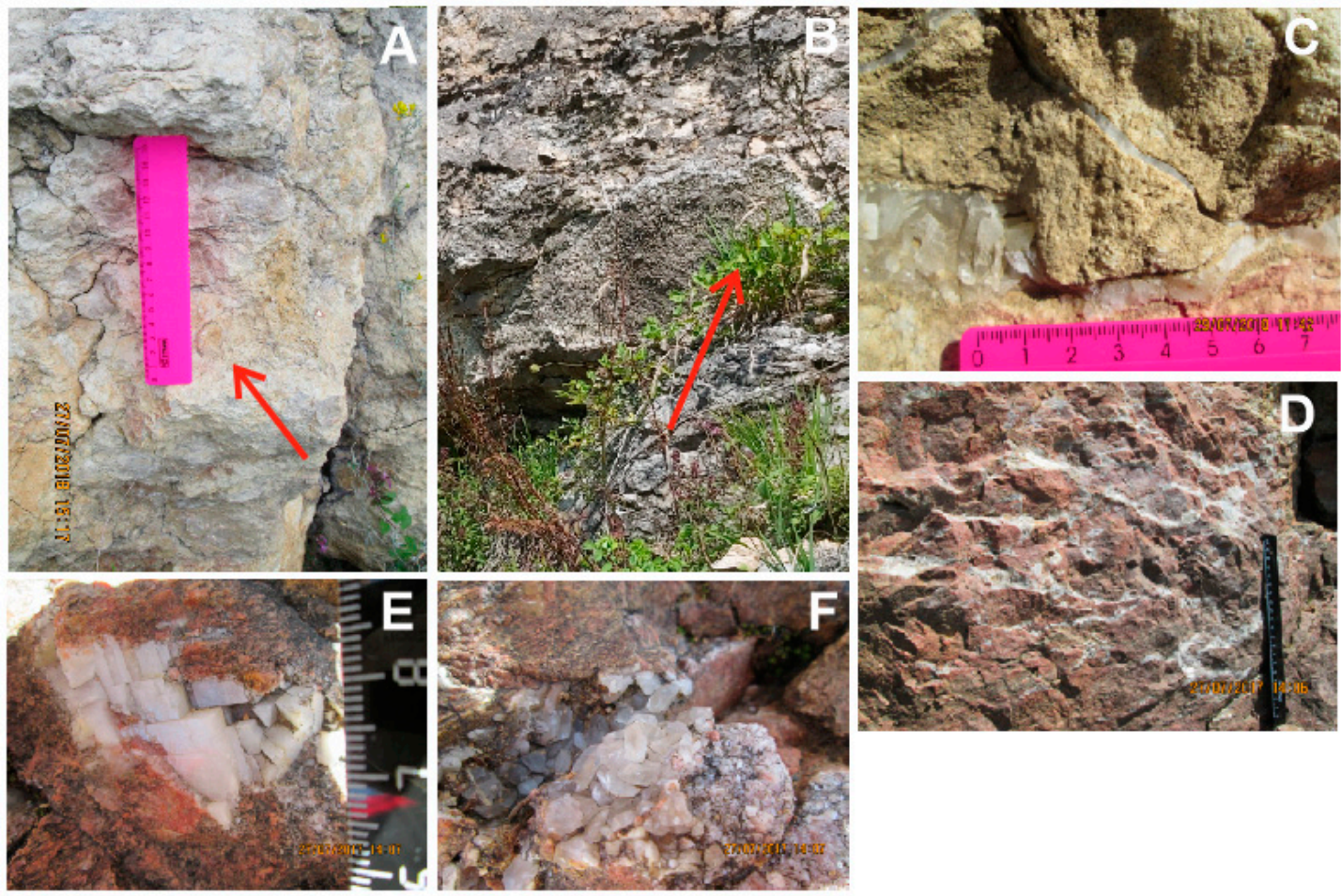

Figure 3. Some notable minor geological features of the Lagonaki Highland: (A) unidentified ammonite in the highly-fossiliferous Upper Jurassic limestones (Tender Cave locality), (B) calcite aggregate on the exposure of the Upper Jurassic limestones (5000 locality), (C) calcite veins in the megaclast of the Upper Jurassic limestones (Partisan Glade locality), and (D-F) the Upper Jurassic red dolostones with calcite veins (Big Azish Cave locality).

The second geoheritage point is the 5000 locality stretching along the Lagonaki-Dakhovskaya road, $\sim 5 \mathrm{~km}$ far from the Belaya River bridge (Figure 2B). This point represents the lower part of the Late Jurassic carbonate complex. Its significance is marked by an occasional discovery of very unusual fossil that is interpreted preliminary as a pharetronid sponge? Muellerithalamia sp. (Calcarea; see taxon description in [18]). The specific features and the rarity of this fossil determine the locality importance 
to scientists. Educators and tourists may find this point less attractive, although its potential to offer interesting fossil findings (e.g., echinoderms) would attract the both university students in geology and amateur collectors. The existence of a spectacular 'spot' (up to $30 \mathrm{~cm}$ in diameter) formed by big calcite crystals on the outcrop wall (Figure 3B) partly recompenses the restricted utility of this point to tourists.

The third geoheritage point is the Partisan Glade locality, which is situated on the southern periphery of the Lagonaki Highland (Figure 2C). Although the local geological landscape is dominated by the Lower-Middle Jurassic black shales, big megaclasts occur here and there along the Yavorova Glade-Guzeripl road. These megaclasts represent the Late Jurassic limestones detached from cliffs of the nearby cuesta-type mountain ranges. Some of them bear representative veins with big calcite crystals of post-depositional origin (Figure 3C). To scientists and educators, this locality is of low importance, but occasional tourists may be interested in looking at these calcite veins that seem to be really spectacular.

The fourth geoheritage point is the Azish Cave locality where the Late Jurassic red-colored dolostones crop out (Figures 2D and 3D). This point has significant importance to scientists. The lithological and geochemical properties of the noted rocks are yet to be fully understood. The results of the preliminary investigations carried out for the purpose of this study imply that these dolostones are dominated by dolomite (96-97\%) (Figure 4) with subordinate amounts of calcite $(\sim 2 \%)$, detrital grains of quartz (0.4-0.9\%), and albite (up to 3\%). Dolostones also include organic matter (up to $1 \%$ ) that occurs between dolomite grains. The rocks are diagenetic by their origin; apparently, many dolomite grains were formed in pore spaces of the former limestones. The dolomites also bear numerous calcite veins, some of which boast by well-shaped, big calcite crystals (Figure 3E,F). The elemental content of the dolostones is summarized in Table 1. Carbon isotope studies show the $\delta^{13} \mathrm{C}(\mathrm{PDB})$ value ranging between -27 and -29 . Taken together, these preliminary results imply specific characteristics of the dolostones and their depositional environment, which require further examination. If so, this geoheritage point is of special interest to geoscientists. To educators, this locality is important to demonstrate typical dolostones as a specific rock type and to speculate about the red color of carbonate rocks (in this case, the color results, probably, from iron enrichment (the content of $\mathrm{Fe}_{2} \mathrm{O}_{3}$ is $0.7-1.1 \%$ ) from the overlying, thick, Fe-rich clays). Potential geotourists include also academic geotourists (i.e., geoscientists) with enough knowledge to judge lithologically- and geochemically-interesting features. Finally, the outstanding aesthetic properties of the entire locality (Figure 3D) and calcite crystals (Figure 3E,F) make it very attractive to tourists.

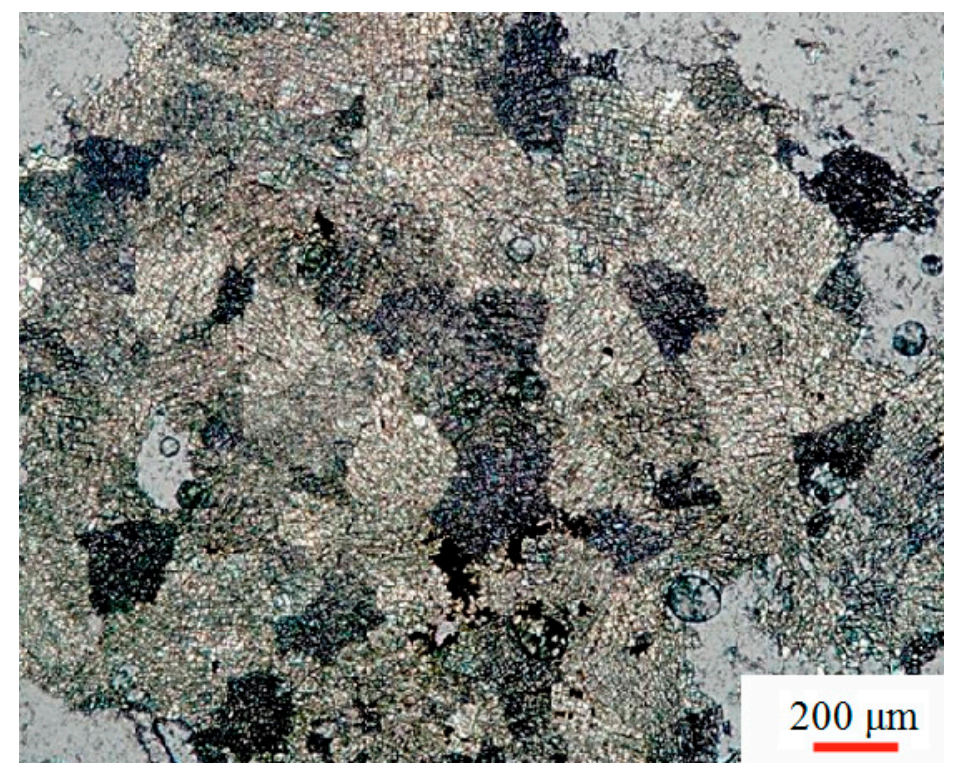

Figure 4. Petrological peculiarities of the Upper Jurassic dolostones; dolomite grains dominate the rock (XPL). 
Table 1. Elemental Content of the Studied Dolostones.

\begin{tabular}{cc}
\hline Element & Content (ppm) \\
\hline $\mathrm{Li}$ & $1.64-2.54$ \\
$\mathrm{Be}$ & $0.14-0.15$ \\
$\mathrm{Ti}$ & $88.07-93.23$ \\
$\mathrm{~V}$ & $4.29-7.64$ \\
$\mathrm{Cr}$ & $5.60-8.52$ \\
$\mathrm{Mn}$ & $77.05-204.64$ \\
$\mathrm{Co}$ & $1.21-2.13$ \\
$\mathrm{Ni}$ & $7.59-12.31$ \\
$\mathrm{Cu}$ & $3.62-8.50$ \\
$\mathrm{Zn}$ & $27.00-63.23$ \\
$\mathrm{Ga}$ & $1.06-1.51$ \\
$\mathrm{Se}$ & $1-83$ \\
$\mathrm{Rb}$ & $2.92-2.99$ \\
$\mathrm{Sr}$ & $141.65-207.90$ \\
$\mathrm{Y}$ & $8.38-17.00$ \\
$\mathrm{Zr}$ & $2.64-3.12$ \\
$\mathrm{Nb}$ & $0.26-0.30$ \\
$\mathrm{Mo}$ & 0.33 \\
$\mathrm{Cd}$ & $0.32-0.86$ \\
$\mathrm{Ba}$ & $11.43-12.73$ \\
$\mathrm{~W}$ & $0.06-0.08$ \\
$\mathrm{~Pb}$ & $1.90-2.13$ \\
\hline
\end{tabular}

\section{Discussion and Conclusion}

The characteristics presented above permit recognition of several geoheritage points dispersed within the territory of the Lagonaki Highland (most probably, the number of such points is much bigger, but the noted points are best-accessible and typical). None of these points deserves recognition as a geosite (with the probable exception of the second point) because of limited uniqueness. However, these points contribute to representation of the geoheritage of the entire Lagonaki Highland and illustrate typical rocks, their fossil content, and some mineralogical peculiarities. These also permit to realize the diversity and the integrity of the local geoheritage landscape. The problem of difference of geoheritage manifestations is significant for detailed geoheritage resource assessment (e.g., [19,20]), and the idea of dispersed geoheritage points permits to solve it partly making a clear distinction between primary, 'traditional' geosites and secondary, auxiliary dispersed geoheritage points. This idea seems to be worth consideration for further refinement of the available quantitative approaches of general geoheritage analysis and description [8,10,21-29].

Dispersed geoheritage points seem to be important to scientists, educators, and tourists. If so, these points can be judged auxiliary, but nonetheless important constituents of the local geoheritage resource. Their special importance is determined by two reasons. First, in order to make general judgments of the local geology, scientists need significant massif of data representing the entire study area, not just its fragments available in geosites and big outcrops (see review of the problem in [15]). In this case, numerous 'secondary-order' outcrops are very important as data from them (if even elementary and small-amount) permit to provide comprehensive characteristics of such a big domain as the Lagonaki Highland. Second, the studied localities are well-accessible being situated along the principal roads sustaining tourist flows to the Stonesea Range, which is the main (geo)tourist destination of the Lagonaki Highland (Figure 5). This is very important to educators and tourists who need demonstration of the local geoheritage in the course of normal-condition excursions. In this case, the low uniqueness of the localities is recompensed by their accessibility and possibility to deliver geological knowledge in a logical way. 


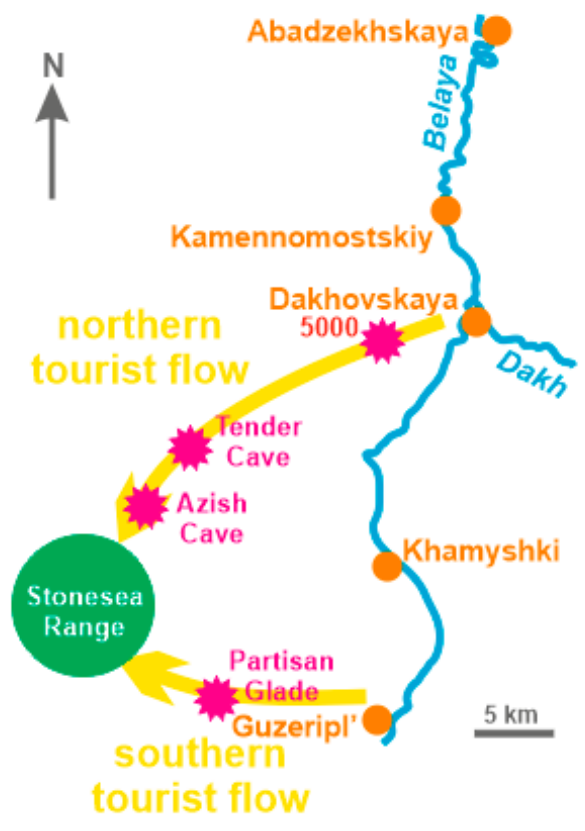

Figure 5. Relations of the analyzed dispersed geoheritage points to tourism activities in the study area.

Conclusively, dispersed geoheritage points constitute a particular class of geoheritage objects. Their principal function is linked to full representation of local geoheritage that permits efficient exploitation of the geoheritage resource. The Lagonaki Highland in southwestern Russia provides a typical example of dispersed geoheritage points. An important question for further discussion is whether big-sized geosites occupying territories measured by square kilometers can be understood as assemblies of geoheritage points.

Author Contributions: Conceptualization, D.A.R.; methodology, D.A.R. and S.O.Z.; formal analysis, D.A.R.; writing, D.A.R. and M.B.R.; project administration, M.B.R.

Funding: The work is performed according to the Russian Government Program of Competitive Growth of Kazan Federal University (contribution of S.O.Z.). The work was supported by the Ministry of Science and High Education of the Russian Federation contract No. 14.Y 26.31.0029 in the framework of the Resolution No.220 of the Government of the Russian Federation (contribution of S.O.Z.). The contribution of D.A.R. was not funded.

Acknowledgments: The authors gratefully thank the journal editors and the three reviewers for their helpful suggestions, Natalia V. Ruban (Russia), Olesya V. Nazarenko (Russia), and Pavel P. Zayats (Russia) for field assistance, Oksana S. Dzyuba (Russia) and Joachim Reitner (Germany) for discussion of some palaeontological material, and Alexei A. Eskin (Russia) and Bulat I. Gareev (Russia) for their help with analytical data.

Conflicts of Interest: The authors declare no conflict of interest. The funders had no role in the design of the study; in the collection, analyses, or interpretation of data; in the writing of the manuscript, or in the decision to publish the results.

\section{References}

1. Bétard, F.; Hobléa, F.; Portal, C. Geoheritage as new territorial resource for local development. Ann. Geogr. 2017, 717, 523-543. [CrossRef]

2. Brilha, J.; Gray, M.; Pereira, D.I.; Pereira, P. Geodiversity: An integrative review as a contribution to the sustainable development of the whole of nature. Environ. Sci. Policy 2018, 86, 19-28. [CrossRef]

3. Gray, M. Geodiversity. Valuing and Conserving Abiotic Nature; Wiley-Blackwell: Chichester, UK, 2013 ; pp. 1-495.

4. Mikhailenko, A.V.; Ruban, D.A. Geo-Heritage specific visibility as an important parameter in geo-tourism resource evaluation. Geosci. 2019, 9, 146. [CrossRef]

5. Muda, J.; Tongkul, F. Geoheritage resources of the Baliajong River: Potential for geotourism development. Bull. Geol. Soc. Malays. 2008, 54, 139-145. [CrossRef]

6. Ruban, D.A. Geodiversity as a precious national resource: A note on the role of geoparks. Resour. Policy 2017, 53, 103-108. [CrossRef] 
7. Wang, H.; Li, J.; Wu, T. Characteristics and Genesis of Geoheritage Resources of Taihang Mountain. Beijing Daxue Xuebao (Ziran Kexue Ban)/Acta Sci. Nat. Univ. Pekin. 2018, 54, 546-554.

8. Brilha, J. Inventory and Quantitative Assessment of Geosites and Geodiversity Sites: A Review. Geoheritage 2016, 8, 119-134. [CrossRef]

9. Bruschi, V.M.; Cendrero, A. Geosite evaluation; can we measure intangible values? Il Quat. 2005, 18, $293-306$.

10. Reynard, E.; Brilha, J. (Eds.) Geoheritage: Assessment, Protection, and Management; Elsevier: Amsterdam, The Netherlands, 2018; pp. 1-482.

11. Migoń, P.; Pijet-Migoń, E. Viewpoint geosites - values, conservation and management issues. Proc. Geol. Assoc. 2017, 128, 511-522. [CrossRef]

12. Ruban, D.A. Aesthetic properties of geological heritage landscapes: Evidence from the Lagonaki Highland (Western Caucasus, Russia). J. Geogr. Inst. "Jovan Cvijić" SASA 2018, 68, 289-296. [CrossRef]

13. Adamia, S.; Alania, V.; Chabukiani, A.; Kutelia, Z.; Sadradze, N. Great Caucasus (Cavcasioni): A Long-lived North-Tethyan Back-Arc Basin. Turk. J. Earth Sci. 2011, 20, 611-628.

14. Guo, L.; Vincent, S.J.; Lavrishchev, V. Upper Jurassic Reefs from the Russian Western Caucasus: Implications for the Eastern Black Sea. Turk. J. Earth Sci. 2011, 20, 629-653.

15. Ruban, D.A. The siliciclastics/carbonates shift in the Jurassic of the Western Caucasus (central northern Neo-Tethys): Reconsidering research over the last 50 years. Geol. 2019, 25, 153-162.

16. Saintot, A.; Brunet, M.-F.; Yakovlev, F.; Sébrier, M.; Stephenson, R.; Ershov, A.; Chalot-Prat, F.; McCann, T. The Mesozoic-Cenozoic tectonic evolution of the Greater Caucasus. Geol. Soc. Lond. Mem. 2006, 32, 277-289. [CrossRef]

17. Veress, M.; Telbisz, T.; Tóth, G.; Lóczy, D.; Ruban, D.A.; Gutak, Ja.M. Glaciokarsts; Springer: Cham, Switzerland, 2019; pp. 1-516.

18. Reitner, J. Phylogenie und Konvergenzen bei rezenten und fossilen Calcarea (Porifera) mit einem kalkigen Basalskelett ("Inozoa", “Pharetronida”). Berl. Geowiss. Abh. (A) 1987, 86, 87-125.

19. Nazaruddin, D.A.; Mansor, H.E.; Wali, S.S.A.S. Geoheritage of Labuan island. Bull. Geol. Soc. Malays. 2016, 62, 117-129. [CrossRef]

20. Phuong, T.H.; Cu, N.H.; Thanh, T.D.; Van Dong, B. Geoheritage values in the Cat Ba islands, Vietnam. Environ. Earth Sci. 2013, 70, 543-548. [CrossRef]

21. Bruschi, V.M.; Cendrero, A.; Albertos, J.A.C. A statistical approach to the validation and optimisation of geoheritage assessment procedures. Geoheritage 2011, 3, 131-149. [CrossRef]

22. Fassoulas, C.; Mouriki, D.; Dimitriou-Nikolakis, P.; Iliopoulos, G. Quantitative assessment of geotopes as an effective tool for geoheritage management. Geoheritage 2012, 4, 177-193. [CrossRef]

23. Forte, J.P.; Brilha, J.; Pereira, D.I.; Nolasco, M. Kernel Density Applied to the Quantitative Assessment of Geodiversity. Geoheritage 2018, 10, 205-217. [CrossRef]

24. Gordon, J.E. Geoheritage, geotourism and the cultural landscape: Enhancing the visitor experience and promoting geoconservation. Geosciences 2018, 8, 136. [CrossRef]

25. Melelli, L.; Vergari, F.; Liucci, L.; Del Monte, M. Geomorphodiversity index: Quantifying the diversity of landforms and physical landscape. Sci. Total. Environ. 2017, 584-585, 701-714. [CrossRef] [PubMed]

26. Nazaruddin, D.A. Selected geosites for geoheritage, geotourism, and geoconservation in Songkhla Province, Southern Thailand. Quaest. Geogr. 2019, 38, 161-177. [CrossRef]

27. Pereira, P.; Pereira, D.I. Methodological guidelines for geomorphosite assessment. Geomorphol Relief Process. Env. 2010, 2, 215-222. [CrossRef]

28. Reynard, E.; Perret, A.; Bussard, J.; Grangier, L.; Martin, S. Integrated approach for the inventory and management of geomorphological heritage at the regional scale. Geoheritage 2016, 8, 43-60. [CrossRef]

29. Serrano, E.; Ruiz-Flano, P. Geodiversity. A theoretical and applied concept. Geogr. Helv. 2007, 62, $140-147$. [CrossRef]

(C) 2019 by the authors. Licensee MDPI, Basel, Switzerland. This article is an open access article distributed under the terms and conditions of the Creative Commons Attribution (CC BY) license (http://creativecommons.org/licenses/by/4.0/). 